\title{
Technology in Education: Attitudes Towards using Technology in Nutrition Education
}

\author{
Asrar Sindi ${ }^{1}$ \\ Faculty of Humanities and Social Science \\ Newcastle University \\ Newcastle, United Kingdom
}

\author{
James Stanfield ${ }^{2}$ \\ School of Education \\ Newcastle University \\ Newcastle, United Kingdom
}

\author{
Abdullah Sheikh ${ }^{3}$ \\ Department of Computer Science \\ Taif University \\ Taif, Saudi Arabia
}

\begin{abstract}
Digital technologies have influenced how teachers conduct the daily practice, and students learn in classrooms. In addition, technology is increasingly being deployed in the classroom environment via a combination of kinesthetics', visual's and auditory approaches. This paper aims to investigate teachers' and students' attitude towards using technology in nutritional education. Then, it discusses the impact of online games to enhance nutritional education of students. After that it will discuss the implication and findings of applying learning games to the curriculum from both teachers and students perspectives.
\end{abstract}

Keywords-Technology; application; online games; nutrition; education

\section{INTRODUCTION}

During the recent years, the education landscape has transformed drastically. Accordingly, digital technologies have entirely revolutionised the manner in which teachers instruct, and students learn in the classrooms [1]. The copying of sentences on the blackboards and the habitual use of textbooks are no longer the only approaches utilised in ensuring learners are engaged. Currently, the world is highly dependent on technology every day. Technology is increasingly being deployed in the classroom environment via a combination of kinaesthetic, visual, and auditory approaches [2].

knowledge in an exciting and interactive manner [3]. For instance, the usage of whiteboards or classroom clickers enables educators to vary their teaching techniques while reinforcing the learning materials.

Technological devices have enhanced cooperation and communication within and beyond the classroom environment. McKnight et al. [4] note that learners can share an opinion on various learning social networks, develop multimedia presentations, undertake research and surveys, attend webinar sessions, or even take part in live discussions with other learners positioned in different geographical areas [5].

Nutrition-associated health conditions like hypertension, obesity, and diabetes that are prevalent from children to adults, are increasing the importance of nutrition education [6]. The outcome of such conditions involves physical discomfort, low self-esteem, negative impact on the overall social health, poor physical health, increased healthcare costs, poor academic outcomes, and a higher likelihood of poor health during adulthood. Thus, there have been calls to employ various prevention strategies, including deploying nutrition education among children and adolescents [7]. Habits like eating are shaped at a young stage in life and schools provide an environment that assist in shaping what people eat and creating awareness of its importance, leading to proper growth and development of students [8].

Researchers such as Adams et al. [9] assert that schools are believed to be the most effective environment for preventative nutrition studies. Also, they argue that nutrition education curricula offered in learning institutions have positive implications, including behavioural and psychosocial effects as well as physiological impact. In addition, various stakeholders guided by evidence-based research, are advocating for comprehensive nutrition and public health education throughout the learning process [10]. In nutrition education, technologies are being utilised, McEvoy et al. [11] revealed that teachers use handson activities from moderate to a high degree in educating students about nutritional concepts. In another study, students and educators reported that computer applications could be beneficial in nutrition education [12].

An investigation made by Yang et al. [13] concerning the importance of technology in nutrition education revealed that the use of technologies in learning at schools are increased such as using such as video, the internet, and computer-assisted programs. Teachers argued that technology improves discussion, collaborative learning, as well as simulations, practices, and role-playing, thus enhancing the learning process and experience [14].

A positive attitude towards technology is broadly recognised as an essential prerequisite for its effective deployment in learning. On the other hand, Rosi et al. [12] demonstrated that a negative attitude could be a detriment to the utilisation of Information Communication Technology (ICT) in schools. Attitudes toward ICT among learners and teachers are influenced by a number of factors such as level of technological capability, support, encouragement, confidence, availability, training, and policy [11]. Strasburger [14] notes that nutrition educators and learners are prepared to integrate technology into their classrooms effectively. Rosi et al. [12] claim that the educators' capability and choice to incorporate technology into their teaching is motivated by several factors. For instance, some educationalists may lack adequate technical abilities for interfacing with technological platforms. Others have been reported to lack technological self-efficiency or integration self-efficiency [14]. In some cases, technical as well as administrative support has been reported to be missing, making it challenging for teachers to obtain finance in order to attend training courses [13]. 
Accordingly, this paper aims to examine the students' and teachers' attitudes towards utilising technology in nutrition education in primary schools.

This paper organised as follows. Section II gives an over view of the features that involved to develop learning enhance education. Section III serves the research literature review to present the impact of using online games to develop students awareness of nutritional concepts, then Section IV explains the research methodology. Then, Section $\mathrm{V}$ discusses the research results and analyses the teachers and students attitudes towards the technology. Finally, Section VI is discussing the research finding, and Section VII concludes explaining the need of developing online games in the purpose of enhancing nutritional learning.

\section{BACKGROUND}

This section serves as a background and a general view of the features that involved to develop learning enhance education.

Deaths throughout the world could result in by Chronic nutrition related conditions, hunger, and malnutrition [15]. Recently, there is a reduction in engagement in physical activities among adolescents and children. Moreover, their eating habits have transformed from traditional food to snacks that are highly unhealthy. According to Vidgen [16], nutrition has a close correlation with mental and physical health. Previous studies concerning the role of school education in shaping healthy eating choices and behaviours among learners have shown positive outcomes. Thus, a nutrition education which models healthy eating lifestyles for students and adopts nutrition programs based on the specific needs of the learners is vital [17].

\section{A. Significance of the Study}

Deploying technology in learning environments, including digital tools like hand-held devices and computers, instils an exceptional experience in both learning and teaching. Technology expands learning materials and course contributions, enhancing 24/7 learning by increasing engagement and motivation while accelerating learning [4]. Furthermore, technology ushers in a novel model of interaction between learners and teachers, boosting the delivery of professional content and resources that assist in personalising learning or customising it. To utilise such benefits for nutrition education and develop a multidimensional technological curriculum, it is vital to comprehend the learners' and teachers' attitudes towards using technology [3]. The outcome of the study will provide insight into the futuristic development of ICT in nutrition education and professional development interventions by scholars and policymakers of the discipline. As new technologies emerge in the educational field, comprehending the perceptions of technology is essential. Furthermore, this research will be valuable for scholars intending to undertake further investigations in relevant fields. It offers insights that will guide researchers adding to the pool of studies concerning the integration of technology in education.

\section{LITERATURE REVIEW}

The aim of this study is to answer main question of the research: "What is the impact of using online learning games to develop student's awareness of nutritional concepts?" In this paper, past studies concerning the use and impact of technology in teaching and learning, as well as the use of technology in nutrition education will be examined. Thereafter, attitudes towards the deployment of technology in education will be assessed. Furthermore, the section will explore the challenges of using ICT in learning. At the end, games in education will be explored, followed by reviewing games for nutrition.

\section{A. The Use and Impact of Technology}

1) Technology in Learning: To provide a context for exploring the attitudes towards the use of technology in education, it is vital to define what constitutes technology. The use of technology in learning and teaching processes, the terminology describing such technology is expanding [18]. The concept is loosely employed to define the various applications of computers and their integration into learning. Technology for education include computer-assisted programs, web-based learning, computer-based education, distance learning, and multimedia [18]. Learning and teaching via technology can be defined as using electronic tools in delivering information and facilitating the acquisition of knowledge or skills. The technologies integrate presentation techniques (the manner in which information is delivered to the students such as video, interactive TV, audio, or multimedia) and delivery techniques (the way information is taught to learners). Additionally, it entails how learners search for knowledge and share it with peers [19].

Despite the different kinds of technology utilised in education, it is commonly agreed that they intend to foster flexibility by offering various learning approaches through electronic devices [18]. While studies concentrate on computer-assisted technologies, there are numerous learning and teaching technologies that are not supported by computers [20]. These teaching technologies include visual documentary show, television, DVD/VCR, overhead projectors, sound systems, models, and tape recordings [21]. In this study, technology will be utilised to refer to various kinds of equipment for teaching and learning. The technologies include computer-based, software, web-based learning, and hardware [18]. Mayer [22] observed that the learning process is improved when pictures and words are integrated to offer an interactive experience to the learners which grasps their attention. Accordingly, learners taught using multimedia applications found it much better than those taught with the conventional method. Su [23] analysed the impact of technology on the performance of students in science subjects with the assistance of educational software. The outcome of the study demonstrated that the application of technology contributed positively to learning and affected the attitudes towards learning science subjects. In the subsequent section, a detailed exploration of literature is delivered concerning the impact of technology on education.

2) Technology in Education: Literature concerning technology in education has witnessed a spirited debate among scholars and theorists regarding the effectiveness of employing 
technology to assist learners and teachers in education [24]. Generally, the majority of scholars and theorists have a perception that technology enhances learning when deployed in the educational process. There are two groups with different outlooks concerning the deployment of technology in education [25]. Clark [26] argues against the view that technology use can improve the teaching and learning process. Accordingly, technology is just a way that can assist delivering instructions but does not necessarily influence achievement of learners. Technologies do not involve like the teachers role in learning and teaching, but the instructional technique is the active factor that catalyses learning [3].

Other researchers have similar views like [27]. For instance, Jewitt [28] discovered that distance education that deploys technological tools does not vary significantly from the traditional approaches to teaching. Concerning distance learning, the researchers made a case that conventional and technologically-based strategies are both effective and they can substitute each other depending on the situation. The authors concluded that learners should not solely rely on distance learning since it is costly as compared to the conventional course learning. Furthermore, Nomass [29] argues that learning or education is a process that involves a series of stimulusresponse linkages. Considering the different views concerning the relationship between learning or teaching and technology, the significant question among researchers is how technology can enhance learning.

Kirkwood and Price [3] argue that there are appropriate and inappropriate applications of technological resources in the classroom. The appropriate application can effectively facilitate learning while inappropriate usage can obstruct it. For instance, a laptop can be used to research and view learning materials or it can be employed by learners in wrong ways like sharing pictures that are not classroom-related resulting in time wastage. Therefore, technology should tap into the cognitive process of learning [25]. Encoding achieved via visualisation can be accomplished using technology. Part of the role of the student is putting information into memory utilising some visual cue, a mathematical instructor can employ a computer to show 3D images of molecules [28]. Such visualisation is richer and more detailed as compared to trying to draw 2D images on the chalkboard; hence using technology simplifies the learning and remembering process.

Nonetheless, technology is a double-edged sword, and when the instructor does not employ it in the right manner due to poor training in pedagogy, it can be less effective [29]. Being aware when to deploy technology in the classroom can significantly assist learners to comprehend materials [24]. Technological advances like simulations or expert systems can offer experimental learning which cannot be achieved using traditional textbook approaches. However, the learning process does not simply change due to the use of technology. Technology enables one to access more information quickly and efficiently. The learners can use less time looking for information and more time on making decisions. On the other hand, the teachers can grasp the attention of learners easily and instruct them using more than one approach that impacts on more than one sense [29].

Currently, several benefits have been identified in utilising digital learning and teaching approaches. Kelly et al. [24] note that technology can enable learners aged between five to eighteen years to access information and learn in an interactive manner. One of the important benefits is raising the accomplishments of students such as greater control over the learning process, rapid acquisition of knowledge, and better performance in tests and exams. Higgins et al. [30] offer a summary of quasi-experiments concerning the role of technology in raising school accomplishments. Accordingly, there is a positive correlation between technology and educational outcomes. Hall [31] found a positive association between ICT utilisation and achievement in a study undertaken in England regarding design technology, maths, foreign languages, and science. Papastergiou [32] demonstrated a connection between high usage of ICT and improved performance in learning and academic achievement. In another study undertaken in Taiwan by Tamim [33] concerning the impacts of digital technologies and resources on elementary students, $92 \%$ of the learners exhibited a positive impact due to the use of computer-assisted learning and teaching.

However, $8 \%$ showed negative impacts favouring the traditional approach. Studies have also examined how technology impacts literacy levels among learners. For instance, Archer et al. [34] carried out a meta-analysis to examine the outcomes of prior studies that considered the effect of technology on literacy and language learning [35] [36]. The study, overall, revealed a relatively minimal but positive impact of the use of technology on literacy. In addition, classrooms with small numbers of learners tend to show a significant positive impact as compared to classes with many learners. In a meta-analysis conducted by [30], it was demonstrated that digital learning and teaching enhance writing skills such as spelling or reading. Hess [37] explored the effect of utilising e-books and e-readers in the classroom environment amongst learners from the USA aged between nine to ten. The outcome of the study indicated that there was a significant variance in reading achievement for the students who used e-readers with scores increasing for both boys and girls. Thus, technology use seems to have varying impacts on literacy levels. Lysenko and Abrami [38] examined the deployment of two technological tools including online gaming tools in relation in reading comprehension among learners aged from six to eight years old. The results obtained show a slight improvement in reading comprehension.

According to Jewitt [28], technology in science can be used in taking pictures and presenting background information regarding various aspects of learning. In this way, concepts could be more accessible and easier to learn, as well as facilitating project-based learning which is vital to the learners. In another study, Hsu et al. [39] examined the impact of incorporating self-explanation ideologies into technological tools to facilitate the students' conceptual learning regarding light and shadow. The study entailed students from eight to nine years old. Based on the results, while there was no statistically significant variance in test scores of the control and experimental groups, Hsu et al. [39] observed significant variation in the retention scores, whereby retention involves holding a learner in a given grade instead of moving with other students to the next grade when he/she has not acquired basic proficiency in learning. The experimental group using technology performed better than the control group. Moreover, in a study focusing on the use of technology-enhanced teaching in chemistry by Guven and Sulun [40], a significant variation 
was found among the control and experimental group.

Higgins et al. [30] observed that technology could assist secondary school students with relatively low literacy levels. Investigations on knowledge and comprehension in social studies before and after utilising online dictionary and thesaurus indicated that there was a significant improvement in knowledge and understanding. Furthermore, Reed et al. [41] revealed that technology could assist learners to catch up with others. The Phonics programme (a technique utilised to teach children reading and writing in English by mixing English sounds to form words) enables digitally assisted students in improving their spelling and reading. An investigation conducted by Tamim et al. [42] using several studies revealed that word processing could positively impact the writing skills among weaker students.

3) Use of Technology in Nutrition Education: The importance of appropriate diet is similar for adolescents, children, and adults. Nutrition education is perceived as an effective tool that can be provided to people using various approaches at the individual, policy, and community levels [43]. Samieipour et al. [44] defined nutrition education as a combination of various educational approaches intended to facilitate or encourage learners to make healthy choices and nutritional behaviours. Consequently, nutrition education can result in improvements in the health and welfare of students. The school-based nutritional knowledge delivery and acquisition is known to be an effective approach in ensuring a positive nutritional attitude and right habits. Hence, policymakers have attempted to include health promotion educational strategies in education to enhance self-efficiency and alter the behaviours of families and learners. Also, they note that nutritional programs can only be effective when guidance is established based on the attitudes, performance, and knowledge. Kupolati et al. [45] examined the impact of teachers' perception on the school nutrition education and how it influences eating behaviours of students in the Bronkhorstspruit District schools located in South Africa. Results obtained demonstrated that the support for nutrition education among schools was limited undermining the ability of schools to influence healthy eating habits among learners. Thus, there is a need to enhance the educators' capability to model a positive eating habit. Also, they revealed that learners were not entirely unaware of healthy eating, but they had limited ability to influence behavioural changes due to the resource-constrained settings. Furthermore, they argue that to encourage healthy eating habits, it is vital that unhealthy choices of food are discouraged, especially from the food vendors; peer influences should also be avoided.

Previous studies have established the importance of attitude and teachers' role in encouraging healthy eating among students. The teachers' responsibilities include adopting nutritional curriculum and modelling healthy choices [46] [47]. However, little is understood concerning the teachers' attitudes to various aspects regarding nutritional eating. Ercan [48] considers nutrition education as a scientific unit due to the rising obesity in the modern world. Accordingly, healthy nutrition is a vital condition for a healthy life because unhealthy eating habits result in some disease.

According to Cooper et al. [49], the right nutrition is significant to cognitive functioning in adolescence and children attending schools. The authors showed the effects that consum- ing a healthy breakfast had on the level of student's concentration at school. Cooper et al. [49] compared the performance of learners who did not have breakfast with the learners who ate breakfast. O'Dea and Abraham [50] examined the level of knowledge, attitudes, and beliefs that the physical education and home economics tutors had towards eating disorders and obesity problems. The intent of O'Dea and Abraham [50] was to explore the extent to which teachers and students were informed of their wellbeing. As a result, it was identified that a positive attitude of teachers has positive implications in assisting learners to adopt healthy eating habits. Generally, these kinds of studies have different weaknesses since their results were restricted due to the availability of literature that increasingly focused on young children or adults as there were no previous studies conducted by employing adolescent subjects. Moreover, the study by Cooper et al. [49] was limited by a small sample size that did not offer comprehensive results. Sharma and Rani [51] studied the changes in knowledge of IT professionals after nutrition education was delivered digitally for a month. Thus, the study demonstrated that the provision of nutrition knowledge via technology greatly aids in promoting healthy dietary habits.

In addition, there are nutrition curriculums that are aligned with units such as mathematics, social sciences, languages, and arts. One example is the Dairy Council of California K-12 [52]. Each grade in the program possesses a specific curriculum with ten lessons on nutrition. The lessons are made using a behavioural change mechanism that encourages students to eat healthy. Through this program, children can exercise long-term health related skills such as setting a goal, making decisions, and analysing effects. The plans are fun and simple to use, as well as effective for the education of students in general. These are important in the development of the child, cognitively and physically too. Most of the foods and nutrition programs are designed for the students in school. Nutrition educators must be informed and take part in discussions concerning access to information technology. Due its growing importance, in developing countries, there are trends appearing in technology that can support education about nutrition to students [52]. Such technology can be effectively utilised in both nutritional education and other aspects of teaching.

\section{B. Attitudes Towards the use of Technology}

Baturay et al. [53] define attitudes as inclinations, bias, fear, convictions, feelings, preconceived notions, prejudices, and ideas concerning a given matter. In psychology, attitude entails a psychological construct, as well as an emotional and mental entity that inheres within an individual and characterises him/her. Moreover, it is organised by experience and exerts dynamic and directive influence on a person's response to objects or situations. In the context of this research, attitude represents the conceptual value of various technologies in the users' mind but not the benefits of the technologies themselves. The usage of technology in education seems to have led to a conflict between individuals who have a negative and positive attitude towards deploying ICT as a learning and instructional tool [54]. Negative attitudes toward educational technologies have been attributed to lack of confidence, insufficient technical support, or lack of pedagogically driven training concerning technology [16]. To comprehend attitudes regarding ICT deployment in education, Condie and Munro 
(2007) argue that it is vital to understand concerns that are an integral part of teachers and learners' attitudes. According to Awan [54], these concerns can be categorised as perceptions, feelings, attitudes, and motivations that learners and teachers experience while utilising technology.

Mumtaz [55] argues that before, during, and after the implementation of a novel model, learners and teachers undergo various psychological phases regarding their concerns towards technology. Such concerns can be categorised into three phases including concerns for the self, management and implementation concerns, and concerns about the effect of technology on teachers and learners. That is to say, educational technologies should have a goal of assisting individuals to become more independent by defining the targeted behaviour, functional reinforcement, selecting self-management approach, teaching the use of self-management technologies, and instilling independence. Awan [54] indicates that the present consensus stipulates that a timely determination of the concerns can be important too, in case a learning institution wants to ensure prosperous implementation of technology.

Meerza and Beauchamp [56] examined the attitudes and critical factors affecting the usage of ICT among undergraduates in Kuwait universities. The study found that language, ICT support, and type of institution impacted on the perception towards technology. When the learners and teachers have a positive attitude towards technology, it is likely to be integrated effectively into the learning process. For instance, Rhoda and Gerald [57] demonstrated that a positive attitude is a prerequisite towards using technology in learning. Some of the indicators of positive attitude include improving the presentation, engaging, and making a lesson interesting. On the contrary, some scholars have found that technology can result in negative attitudes including making lessons less interesting, the concepts taught becoming difficult to understand, obstructing learning, and reducing motivation [58] [59] [60].

Balta and Duran [61] examined the attitudes of teachers and learners towards the deployment of interactive whiteboards in elementary as well as secondary school classrooms. The findings from the study revealed that interactive whiteboards are rated highly by learners and students. It was noted that as the learners mature, their attitude towards the use of interactive whiteboards as a technological tool for learning becomes negative. Enayati et al. [62] investigated the attitude of teachers towards the implementation of technology in education in the City of Babol. The teachers increasingly believe that technology has significant benefits and enhances efficacy and effectiveness in education.

Dogruer et al. [63] examined the attitudes of primary school teachers of English language towards utilising educational technology by administering questionnaires. The study showed that there was a positive attitude especially concerning the impact technology has on knowledge acquisition and improving the achievement of students. Furthermore, a study by [64] examining intern teachers' attitudes towards technology indicated that a positive attitude was found with no significant gender differences. Moreover, the study revealed that there are no considerable variations between the field of teaching or subject. Kabadayi [65] undertook an exploration of preschool teachers as well as part-time teachers to determine their attitudes toward multimedia in learning. According to the findings, 75 technologies. Similar findings have been documented in Zanguyi's [66] study examining educators' attitudes toward the deployment of technology in learning. In another recent study, Seraji et al. [67] examined the attitude towards ICT usage amongst teachers originating from various institutions in Mazandaran. The sample involved 62 female and 38 male teachers, and the findings demonstrated that there was a statistically significant correlation between the attitude of teachers and their experience with technology. When the teachers have a positive attitude, technology is perceived positively. Moreover, Seraji et al. [67] discovered that there was a statistical relationship between the teachers' tenure and age with their attitude towards ICT. That is, younger teachers have a considerably more positive attitude towards the use of technology as compared to older teachers.

Chow [68] indicates that age does not determine the teacher's attitude toward technology. However, the extent to which an educator is comfortable and has comprehensive training on technology, directly affects educator's perception towards it. Thus, [68] highlights some of the challenges that may make teachers have a bad attitude towards technology: lack of comfort with ICT, the belief that technology does not assist students to learn, lack of interest, inadequate training, and lack of access to technology. A study by Albirini [69] examined the attitude towards the use of ICT for both teachers and learners. The investigation examined perception, performance, and motivation as well as participation in ICT classrooms. The study's results revealed that there is no significant difference in using modern technology in schools between the learners and educators. Nonetheless, it was noted that online resources help students in learning at their own speed. Moreover, ICT resources motivate teachers and learners as they are interesting and interactive, making teachers and learners value ICT as an effective learning tool [70].

Al-Emran et al. [71] indicate that since the learners are generally on task (use technology to learn and research), they are likely to show positive feelings towards the use of technology or computers as compared to doing their work using conventional approaches. Furthermore, the quantity of non-tasked oriented habits reduces considerably in computer classroom sessions due to the use of multimedia tools for spelling or reading. Hence, the use of digital video as a learning tool can enhance on-task concentration. According to Hwang and Chang [72], the use of modern technology cannot fully replace conventional learning activities but easily complement them. Baturay et al. [53] found that learners with low levels of motivation as well as a feeling of uncertainty about learning can demonstrate positive habits in the course of lessons that utilise computers as compared to the traditional approaches. Shroff et al. [73] revealed several positive perceptions and attitudes among students due to the use of technology, including enhanced class attendance rates, improved cooperation among students in learning, and increased research of learning materials outside the school. Additionally, there is increased self-esteem and selfconfidence among learners with laptops. Tseng et al. [74] found that learners are more motivated as they find ICT more appealing, pleasant, and fun compared to traditional approaches. Thus, the use of technology in the classroom is increasingly viewed with a positive attitude among most teachers and learners due to its interactive and interesting experience. 


\section{Challenges of Deploying Technology in Learning}

According to Al-Fraihat et al. [75], there are several hurdles to overcome when a learning institution wants to deploy technology effectively. Awan [54] claims that studies about the challenges or barriers to deploying technology in schools indicate that attitude is a major issue. The fact that some learners or teachers can resist change due to personal beliefs has been examined as a challenge to implementing technology in learning institutions. A school's organisational structure can cause resistance to successful integration of ICT. Condie and Munro [76] present a framework that offers barriers that limit the use of technology in schools, depicted in Fig. 1.

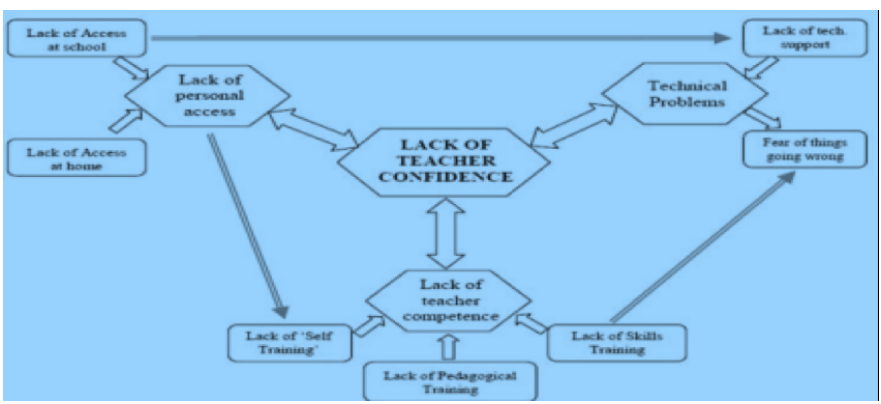

Fig. 1. Barriers to the Deployment of ICT, Source: (Condie and Munro [76]

Hwang and Chang [72] highlight the factors impacting the perceived ease of technology use. The positive factors include regular usage and experience in technology, confidence in utilising technology, owning a computer, and training. The detrimental factors include insufficient access to resources, a challenge to use hardware/software, and lack of technical support [77].

Lack of technological and computer skills is one of the burdens of implementing and having a positive attitude towards the use of technology [75]. Some teachers and students might have basic computer training, technologies keep evolving [75]. Hence, there is a need for regular pedagogical training concerning emerging technologies for them to be updated on recent developments in the field of ICT use in education. Furthermore, training without continuous practice can have minimal impact since people tend to forget. Thus, training is considered a big challenge in deploying technology in learning. At times, before introducing novel technologies, teachers do not receive training regarding their use. Thus, they end up trying to figure out how to use the technology themselves. Osang et al. [78] note that offering training related to the technological features is just one aspect of ensuring successful implementation. The real training related challenge entails training for changes to pedagogical approaches. Blinco et al. [79] assert that technology implementation success rests on the fundamental need that teachers, as well as learners, possess sufficient technical skills to employ technological tools effectively.

Al-Fraihat et al. [75] note that it is normal for all human beings engaged in activities to experience fear of change and resistance since people tend to be more comfortable in holding to the old strategies and processes instead of adapting to new ways. Moreover, the change from old practices to novel ones can be challenging to any entity, be it an elementary institution or higher learning institution [80]. The challenge is attributable to the involvement of massive upfront capital, time, planning, disruptions, downsizing, an increase of workforce, or organisational changes [78].

There is also the fear of being rendered redundant by technology. This is attributed to the fact that people believe that technology minimises the value of teachers once adopted, since they might be dispensed as technology takes up their roles [81]. Hence, teachers might have a negative attitude that can be detrimental towards adopting and using technology as an instructional tool. Moreover, Sethi et al. [82] observed that some institutions lack adequate facilities and resources that have influenced the deployment of ICT in learning institutions. An exploration by [77] indicate that some schools do not have the basic office gadgets such as projectors, computers, binders, printers, and other devices to facilitate the use of technology. In a recent study, Tondeur et al. [80] indicate that it is appalling that some learning institutions do not have access to internet connections. Furthermore, with the spread of technologies throughout the globe, internet security is becoming a major challenge. Specifically, the internet has led to a bad reputation due to fraud, resulting in a fear of electronic transactions. For instance, students can easily outsource their assignments, resulting in loss of trust in the ultimate achievement of learners [77]. Regarding attitudes and beliefs playing a vital role in the adoption of technology, Mayes et al. [83] created a two-phase categorisation that identifies beliefs and attitudes to be the second order challenges that hinder the learners and teachers from utilising educational ICT. The first order challenges involve the obstructions that are external to educators such as infrastructure, training, resource allocation, support, and other software/hardware challenges [82]. The second order barriers are described as the challenges that are internal to the teachers or learners including skillset and confidence that are frequently overlooked [83]. While Osang et al. [78] argue that the first order challenges are important, they suggest that the second order challenges are likely to be more obstinate when infrastructure and resource challenges are alleviated. Table I. shows the first and second order challenges impacting the use of technology.

TABLE I. First AND SECOND-ORdER Challenges [77]

\begin{tabular}{|l|l|}
\hline $\begin{array}{l}\text { First-order-Barriers } \\
\text { (INSTITUTIONAL) }\end{array}$ & $\begin{array}{l}\text { Second-order-Barriers } \\
\text { (INSTITUTIONAL) }\end{array}$ \\
\hline Extrinsic to the teacher & $\begin{array}{l}\text { Intrinsic to teachers (and possibly } \\
\text { subconscious or 'private theories') }\end{array}$ \\
\hline Lack of access to technology & $\begin{array}{l}\text { B eliefs about teaching (and learn- } \\
\text { ing) }\end{array}$ \\
\hline $\begin{array}{l}\text { Insufficient time to plan for inte- } \\
\text { gration }\end{array}$ & $\begin{array}{l}\text { Beliefs about computers and tech- } \\
\text { nology }\end{array}$ \\
\hline $\begin{array}{l}\text { Inadequate technical and admin- } \\
\text { istrative support }\end{array}$ & $\begin{array}{l}\text { Beliefs about classroom practices } \\
\text { and routines }\end{array}$ \\
\hline Lack of training & $\begin{array}{l}\text { (un) Willingness to embrace } \\
\text { change }\end{array}$ \\
\hline
\end{tabular}

\section{Games in Education}

Some of the instructional approaches that employ technology include group discussions, computer-enhanced learning and lectures, or games. Anderson and Barnett [84] studied the use of digital games among learners aged between twelve and thirteen years in America. The study found that digital games 
enhanced the comprehension of electromagnetic concepts as compared to students utilising traditional approaches to learn similar concepts. A study by Albirini [69] noted that online resources, as well as games, assist students in learning at their own pace. Also, Condie and Monroe [76] reveal that digital learning and teaching of science made it more interesting, relevant, and authentic to the students.

Online educational games require learners to employ logic, memory, critical thinking, and problem-solving as well as discovery and visualisation [85]. Additionally, the use of such games requires students to manipulate virtual objects through electronic tools and learn complex elements being modelled. Just like other technologies, online learning games have been found to be effective in increasing motivation as well as learners' interest. Nonetheless, the extent to which this translates into effective learning is not obvious [86]. This is attributed to the lack of empirical data because of few systematic investigations on online games and their cognitive effects.

Researchers have attempted to determine the benefits of online games in learning and why the learners find them interesting. According to Young et al. [87], what makes an online game more fun can be explained using psychology and biological functioning of the body. Motivation originates from sensory gratification, adrenaline, engaging environment, roleplaying, taste, the element of fun, and personality. For that reason, games generally motivate players with topics like a survival strategy, building relationships, and roleplaying. Kapp [88] argues that online games can manipulate the unchanged variables based on simulations of natural systems. For instance, in the game SimEarth, learners can observe the impacts of altering the universal oxygen levels or increasing temperature. Thus, the learners can view a perspective from a novel viewpoint [89]. In the Hidden Agenda simulation, students can assume the role of a president in America and learn about sociology, culture, economics, or politics in the process. Young et al. [87] indicate that games are vital in the mental and social development of learners. In an exploration to establish the games loved by learners in the teaching environment, a group of twenty learners played commercial games (Duke Nukem 3D, Simple, Zork Nemsis and Red Alert) [90]. Findings obtained demonstrate that learners prefer 3D adventure (Zork Nemesis) as well as Strategy (Red Alert) games compared with others. Learners ranked game aspects such as memory, problem-solving, logic, and visualisation to be important [90]. These aspects are found in adventure games and are considered essential in the learning process.

With many developers emerging, online game applications are increasing. This has led to several debates concerning the future of online gaming. Some believe it is hard to forecast the future of gaming since significant technological changes are occurring throughout the world, based on how rapidly technology is developing [91]. Not with standing, online gaming will benefit from the continued advancement of online technology. Some researchers believe that the future of online gaming will include an augmented reality as a standard experience whereby players will be in the same room with their adversaries or will be able to see the other players [92].

\section{E. Games for Nutrition}

The Institute of Digital Media and Child Development Working Group on Games for Health [93] explored the use of video games in nutrition and health education. According to Taylor [94], games such as My Plate Match could help students to learn about groups of foods and the necessity of each group for healthy consumption. This game mainly targets children aged five to eight years old. It is imperative useful platform for students to gain information about eating habits and a balanced diet. This game takes about 10 minutes and can be used in places where there is internet connectivity. This game application teaches the students to recognize foods that do not fit into any food group, known as extras. Similarly, Granic et al. [95] attribute the effectiveness of video games to the ability of engage with other people who are playing them compared to other media. Studies have found that more than $29 \%$ of video game players involve people who are eighteen years or younger. The video games for health are created on platforms that most players are very familiar with such as personal computers, smartphones, game consoles, or web browsers. Moreover, online game is called Mission Nutrition. It has three main tasks; the first task involves critical thinking where the child can determine the kind of foods that have a lot of sugar [96].

The second objective is to look for a snack that provides proteins and carbohydrates while the third task is to test their knowledge about fruits. However, this game ends quickly when learning becomes interesting. The player may search for sugary foods which might promote poor nutrition for the child. Online games are interactive, and it is the role of teachers to proscribe non-interactive media that do not promote health education. Children in schools should learn how to possess cognitive and social skills in the technological world. The main goal of the game is to not only choose the correct answers but also learn about different foods and their effect on the body [94]. Various video games are being created and deployed across a wide array of medical issues, including pain management, human immunodeficiency, cystic fibrosis, and even obesity. Such games are developed for all ages. One of the online games that was developed for use in education was the Immune Attack which was created by the Federation of American Scientists (FAS) [97]. The intent was to teach complex immunology and biology subjects. In the game, a teenager with a distinctive immunodeficiency needs to teach their immune system how to function properly, failure to which he/she risks losing his/her life. The human body acts as the playing field while the immune cells fight viral and bacterial infections with each level featuring a different infection [98]. Another game named Awesome Eats, which is supported by Whole Kids Foundation [99]. The game starts with a chapter that has a "Did You Know?" statement. It allows the students to choose the foods that are not good for their body and those that promote optimum health. After that, ratings are assigned after each level and advances with excellent playing. It is an interactive game for the students who play effectively under a timed challenge. Furthermore, Ship to Shore is also a game that allows students to make choices about the supply of food [100]. It utilises nutrition as a vehicle to also integrate other subjects such as arts, science, and mathematics. 


\section{Methodology}

This study will answer the main question of the research: "What is the impact of using online games to develop student's awareness of nutrition?" by exploring the following questions:

1) What is the impact of using online learning games to develop students' awareness of nutritional concepts?

2) What are the attitudes of learners and teachers towards the use of online learning games in nutrition education?

3) What are the perceived challenges by learners and teachers towards using online games in nutrition education?

The choice of a research method is an important element because it determines the outcome of the research, how the research questions will be answered, and what needs to be done to ensure that right results have been achieved [101]. A good research method makes it possible to collect sufficient data, analyse it appropriately, and give the right output. Bryman [102] explains that research methods are a way of explaining the beliefs and philosophical understanding of the researcher, and thus are in a position to provide a theoretical background of the research. Therefore, this section will explain the research paradigm and approach taken. Subsequently, methods used, as well as the ontology and epistemology of the theoretical framework of the researcher will be identified. Thereafter, the participants and data collected will be described. The last section will discuss the limitations.

\section{A. Research Paradigm}

The research paradigm comes from a Greek word that is used to refer to a pattern [103]. The research paradigm was developed to mean the way people think, and thus became part of the methodological approaches [104]. McCusker and Gunaydin [105] explain that the research paradigm focuses on the views, beliefs, and approaches that one follows. There are three forms of research paradigms, which are the positivist, interpretivist, and pragmatic perspectives.

This research will utilise the positivist research paradigm which is focused on ensuring that the data collected is objective. The positivist research paradigm, according to Brannen [101] separates the knowledge from any other person, because data is believed to be a scientific phenomenon that cannot be influenced by personal opinions. Data collected is presented through facts and figures in this paradigm. The emphasis of the research is often on the objective, which focuses on answering the question "what". Therefore, the quantitative research design is seen to be the most appropriate in utilising the positivist research paradigm. Positivists further believe that the researchers collecting data should separate themselves from the data being collected to avoid bias.

Unlike other methods such as the interpretivist that was not selected for this research, the positivist is highly scientific, objective, and results oriented. The use of the interpretivist paradigm relies on the researcher forming personal connections when collecting data from the respondents. This is because interpretivists believe that the knowledge, data, and information being collected is directly related to and cannot be separated from a person who owns it as [106 explains. Interpretivist information is relayed through the experiences and beliefs of a person [107]. Thus, the method using this paradigm is subjective and highly influenced by personalised connections. Data collected during an interpretivist research approach is usually focused on answering the question of how and why, and could lead to lengthy and in-depth data being collected, thus leading to intersubjective outcomes. For these reasons that relate to the interpretivist research paradigm, the method was not deemed suitable for the research.

The pragmatic research paradigm believes in utilising what works, and in most instances combines the use of positivist and interpretivist research approaches. In this case, it was also not selected for use because the research purely agrees with the use of the positivist paradigm.

\section{B. Research Approach, Design}

A research approach can be classified as either being deductive or inductive. A research approach is a way of reasoning, which can help to arrive at a specific or general conclusion about a given subject [108]. This research will utilise the deductive research approach because it involves testing of theories. Landrum and Garza [109] mention that the deductive research approach starts from a specific point of focus such as the selected theory and works towards a more general outcome. This is because the theories being tested at the start involve a hypothesis, and further proving whether they have been proven right or not. The understanding of teachers' and students' attitudes towards technology is an aspect that can be investigated by looking at a tentative theory of whether there is a correlation between two or more variables. This directly relates to the use of the deductive approaches.

This research will adopt a quantitative research design which utilises numerical aspects to collect and analyse data. In other words, a quantitative research design utilises numerical values to represent data. A quantitative approach was adopted as it makes it possible to quantify such aspects as attitude, behaviour, and opinion. The use of surveys has been termed as one of the most effective and objective ways to approach a research question. This research has utilised this method for various reasons that will be justified later in the methodology.

\section{Methodology}

The factors that affect the selection of a methodology are vast. Thus, the researcher has to understand the current study and consider making a choice that is in line with most of the expected outcomes. The factors affecting methodological selection can be divided into various parts such as practical factors, theoretical factors, ethical factors, as well as the nature of the topic. One of the factors that affect research, as mentioned, is the theoretical factors. Precisely, theoretical factors involve the areas of theory that the researcher can relate to, which involve the validity, reliability, beliefs, and representativeness of the research. The validity and reliability of data are aspects that can be tested to prove its authenticity and realness [110]. In this case, the selection of quantitative methods such as surveys provides one of the easily testable data sets for reliability and validity.

The beliefs of the researcher, in this case, played a big part in choosing the research method. Given that the research 
paradigm is positivist and the research approach is deductive, the philosophical perspectives coincide with the choice of a quantitative research method. Representativeness involves whether a research can cover a sample that is appropriate enough to showcase all the characteristics of a given population [106]. The choice of certain methods limits the selection of a wider sample, such as the use of interviews, which can only be done at length to a select number of respondents. However, methods like questionnaires can be administered to a wider population, hence highly representative [109], which is why the method was chosen. Practical factors include time, costs, funding, access to respondents, and personal skills. Large research might be time-consuming because they require lengthy methods of data collection.

This research considered the average time of conducting data collection and analysis before choosing the method. Conducting research is expensive and could be hard to conduct especially if the source of funding is limited. This research was funded by the researcher and was considered to be within acceptable limits. The access to respondents nearly limited the research, but a certain degree of useful data was collected. Concerning ethics, this research was conducted in a manner that complied with ethical guidelines such as confidentiality and voluntary participation. The nature of the topic is also important in choosing what methods to use. For studies related to understanding "what", analysing attitudes, perception, and behaviour based on a direct relationship, quantitative methods would be best placed to allow for a correlation or regression analysis of different variables. When it comes to sensitive topics that explain for example domestic violence, or areas that focus on explaining what or how in research, there is more likelihood of choosing methods like focus groups, interviews, or observations. This research is geared towards the understanding of attitudes and technology, and thus the choice of quantitative methods was the most appropriate.

\section{Limitations}

Conducting this study in schools requires longer time which could help to obtain better results. Also, using multiple methods such as quantitative together with qualitative. Qualitative such as view of students, teachers, school headteachers, and parents and quantitative such as surveys. Most important is that using online learning games in schools would make teachers notice the difference between using the games and the traditional learning method in students' motivation and comprehension. That would encourage teachers to integrate technology with traditional learning.

\section{Results AND ANALYsis}

This section presents the analysis of data, which was aimed at facilitating the answering of the overarching question in this study. In the context of the research question which was to investigate the effect or the impact of online games on creating awareness about nutrition among students, it was imperative that the study examines the attitudes of students and teachers towards the use of technology. As such, the researcher prepared both students and teachers questionnaires in an attempt to investigate not only the attitudes of students towards technology in learning about nutritional education, but also the attitudes of teachers, who are an important part of the students' learning process. Nutrition education has become one of the most important and widely studied phenomena, and this has primarily been due to the fact that healthy eating has become an important topic in recent times. The increased awareness in some parts of the world on the need to eat healthy foods and the role of technology has challenged researchers to investigate how technology can promote awareness, and whether or not the awareness can equally cut across people of all ages. This is because young people know very little about healthy eating, partly because of ignorance or simply the fact that they do not care much about it. Nutrition education has largely targeted older people, or even in situations where young people have been targeted, they have hardly received this message with the desired enthusiasm. The analysis in this chapter utilised descriptive statistics, where apart from describing the findings, the researcher interprets the intuitive meaning of these figures, clarifying what it means when respondents reply the way they did.

\section{A. Teachers Attitudes}

The attitudes of the teachers towards technology is optimistic, where they believe that the use of technology could go a long way in influencing outcomes even they do not understand how ICT can be used for nutrition curriculum. Moreover, they indicated that they have computers at home and in schools, as a result, they seem quite confident using technology. Teachers, as has been established in this research, embrace technology and highlight its importance in the learning process. The teachers also indicate that online games are an effective form of learning, especially in the context of nutrition education. The teachers also expressed their enthusiasm for using technology such as online learning games supporting having better teaching especially for nutrition education.

\section{B. Students Attitudes}

The students showed enthusiasm when using online learning games to learn, and indicate that learning using online learning games puts them in a better position to understand more about nutrition, and as such, there is need to encourage learning using online learning games. The students, in most cases, do not know much about nutrition, especially when asked about some of the basic elements of nutrition. They, however, indicate their willingness to learn about nutrition using online learning games.

\section{DISCUSSION}

This study revealed that teachers encourage the use of technology in teaching nutrition. This is consistent with existing literature. Digital games enhanced their understanding of electromagnetic concepts as compared to students learning similar concepts by traditional methods. It should be mentioned that, nutritional applications could be more effective when guidance is established based on the attitudes, students' achievement, and experience [44]. Additionally, from the findings of this study, it is observed that most of the students have computers and internet access at home. Thus, the internet has made it easy for online learning games' accessibility in many devices, such as computers and smart devices. This could motivate students to learn about nutrition via technology. What these findings demonstrate is that technology has the ability to influence 
students' perceptions, as well as the effectiveness of using technology in learning. As a finding of this research, once learning is interesting, students become more motivated. This finding has serious implications for the essential growth and development of students in future, as well as their cognitive development [8].

In addition, games could encourage teachers to be innovative and be more effective. They can identify the best materials through observation and give feedback to the students. The study observation of students playing online learning games is that teachers should teach these lessons in groups because students are more motivated and collaborative when they are playing in groups. There are recommendations for games to hold and present more data and information that helps students to interact directly when playing the game. Moreover, there should be food tips at each game level with rewards. So, the information will be acknowledged by students during playing the game in an efficient manner. Also, nutritional development is promoted through playing interactive games in schools and homes. As a recommendation for future work is to develop an application based on online games to enhance nutritional education then to be included with school curriculum.

\section{CONCLUSION}

This paper was aimed to investigate the attitudes of learners and teachers towards the usage of technology in nutrition education in local primary schools. In addition, it focused on exploring the impact of using online games in order to help develop students awareness of nutritional concepts. The outcome of this paper revealed that the attitude of students and teachers towards using ICT for nutritional learning. With that it has also been discovered that using online learning games is an effective method especially to increase nutritional awareness. Teachers showed willingness into teaching using technology. Most of the participants have computers at home as well as Internet access. Furthermore, The use of online learning games can be an impact and efficient method for advancing knowledge regarding healthy eating habits to students. Game designers have took to interest and advantage of this by accomplishing various games for nutritional learning.

\section{REFERENCES}

[1] Howard-Jones, P., Ott, M., van Leeuwen, T. and De Smedt, B., The potential relevance of cognitive neuroscience for the development and use of technology enhanced learning, Learning, media and technology, vol. 40, No, 2, pp. 131-151, 2015.

[2] El-Masri, M. and Tarhini, A., Factors affecting the adoption of elearning systems The Educational Technology Research and Development in Qatar and USA: Extending the Unified Theory of Acceptance and Use of Technology 2 (UTAUT2), Vol. 65, No. 3, pp. 743-763., 2017.

[3] Kirkwood, A. and Price, L., Technology-enhanced learning and teaching in higher education: what is 'enhanced' and how do we know? A critical literature review, Learning, media and technology, vol. 39, No. 1, pp. 6-36, 2014.

[4] McKnight, K., O’Malley, K., Ruzic, R., Horsley, M.K., Franey, J.J. and Bassett, K., Teaching in a digital age: How educators use technology to improve student learning, Journal of research on technology in education, vol. 48, No. 3, pp. 194-211, 2016.

[5] Beckman, K., Bennett, S. and Lockyer, L., Understanding students' use and value of technology for learning. Learning, Media and Technology, vol. 39, No. 3, pp. 346-367, 2014.
[6] DiMaria-Ghalili, R.A., Mirtallo, J.M., Tobin, B.W., Hark, L., Van Horn, L. and Palmer, C.A., Challenges and opportunities for nutrition education and training in the health care professions: intraprofessional and interprofessional call to action, The American journal of clinical nutrition, vol. 99, No. 5, pp. 1184S-1193S, 2014.

[7] Vio, F., Fretes, G., Montenegro, E., González, C.G. and Salinas, J., Prevention of children obesity: a nutrition education intervention model on dietary habits in basic schools in Chile, Food and Nutrition Sciences, vol. 6, No. 13, p. 1221, 2015.

[8] Benton, D., The influence of dietary status on the cognitive performance of children Molecular Nutrition Food Research, vol. 54, pp. 457-470, 2010, Retrieved from http://onlinelibrary.wiley.com/doi/10.1002/mnfr. 200900158/epdf

[9] Adams, K.M., Butsch, W.S. and Kohlmeier, M., The state of nutrition education at US medical schools, Journal of Biomedical Education, 2015.

[10] Naghashpour, M., Shakerinejad, G., Lourizadeh, M.R., Hajinajaf, S. and Jarvandi, F. Nutrition education based on health belief model improves dietary calcium intake among female students of junior high schools, Journal of health, population, and nutrition, vol. 32, No. 3, p. 420, 2014.

[11] McEvoy, C.S., Cantore, K.M., Denlinger, L.N., Schleich, M.A., Stevens, N.M., Swavely, S.C., Odom, A.A. and Novick, M.B., Use of medical students in a flipped classroom programme in nutrition education for fourth-grade school students, Health Education Journal, vol. 75, No. 1, pp. 38-46. 2016.

[12] Rosi, A., Dall'Asta, M., Brighenti, F., Del Rio, D., Volta, E., Baroni, I., Nalin, M., Zelati, M.C., Sanna, A. and Scazzina, F., The use of new technologies for nutritional education in primary schools: a pilot study, Public health, vol. 140, pp. 50-55, 2016.

[13] Yang, Y.T.C., Wang, C.J., Tsai, M.F. and Wang, J.S., Technologyenhanced game based team learning for improving intake of food groups and nutritional elements, Computers \& Education, vol. 88, pp. 143$159,2015$.

[14] Strasburger, V.C., The new technology revolution: collaborative efforts between pediatricians, schools, and millennials for media education, In Media Education for a Digital Generation, Routledge, pp. 83-102, 2015.

[15] Savage, A., Februhartanty, J. and Worsley, A., Adolescent women-a key target population for community nutrition education programs-a qualitative Indonesia case study, Asia Pacific journal of clinical nutrition, 2016.

[16] Vidgen, H. ed., Food literacy: key concepts for health and education, Routledge, 2016.

[17] Hainey, T., Connolly, T.M., Boyle, E.A., Wilson, A. and Razak, A., A systematic literature review of games-based learning empirical evidence in primary education, Computers \& Education, vol. 102, pp. 202-223, 2016

[18] Lai, C., Modelling teachers' influence on learners' self-directed use of technology for language learning outside the classroom, Computers \& Education, vol. 82, pp. 74-83, 2015.

[19] Venkatesh, V., Thong, J.Y. and Xu, X., Consumer acceptance and use of information technology: extending the unified theory of acceptance and use of technology, MIS quarterly, pp. 157-178, 2012.

[20] Thompson, P., The digital natives as learners: Technology use patterns and approaches to learning, Computers \& Education, vol. 65, pp. 12-33, 2013.

[21] Buckingham, D., Beyond technology: Children's learning in the age of digital culture, John Wiley \& Sons, 2013.

[22] Mayer, R.E. ed., The Cambridge handbook of multimedia learning, Cambridge University press, 2005.

[23] Su, K.D., An integrated science course designed with information communication technologies to enhance university students' learning performance, Computers \& Education, vol. 51, No. 3, pp. 1365$1374,2008$.

[24] Kelly, A.E., Lesh, R.A. and Baek, J.Y. eds. Handbook of design research methods in education: Innovations in science, technology, engineering, and mathematics learning and teaching Routledge. 2014.

[25] Cobern, W.W., Contextual constructivism: The impact of culture on the learning and teaching of science, In The practice of constructivism in science education, Routledge, pp. 67- 86, 2012. 
[26] Clark, R.E., Media will never influence learning. Educational technology research and development, vol. 42, No. 2, pp. 21-29, 1994.

[27] Clark, R.E., Reconsidering research on learning from media. Review of Educational Research, vol. 53, No. 4, pp. 445-459, 1983.

[28] Jewitt, C., Technology, literacy, learning: A multimodal approach, Routledge, 2012.

[29] Nomass, B.B., The impact of using technology in teaching English as a second language. English Language and Literature Studies, vol. 3, No. 1, p. 111, 2013.

[30] Higgins, S., Xiao, Z. and Katsipataki, M. The impact of digital technology on learning: A summary for the education endowment foundation. Durham, UK: Education Endowment Foundation and Durham University, 2012.

[31] Hall, R., Towards a fusion of formal and informal learning environments: The impact of the read/write web., Journal of E-learning, vol. 7, No. 1, pp. 29-40, 2009.

[32] Papastergiou, M., Digital game-based learning in high school computer science education: Impact on educational effectiveness and student motivation, Computers \& Education, vol. 52, No. 1, pp. 1-12, 2009.

[33] Tamim, R., Technology integration in the UAE schools: Current status and way forward, Information Systems Applications in the Arab Education Sector, pp.23-38, 2013.

[34] Archer, K., Savage, R., Sanghera-Sidhu, S., Wood, E., Gottardo, A. and Chen, V., Examining the effectiveness of technology use in classrooms: A tertiary metaanalysis. Computers \& Education, vol. 78, pp. 140149, 2014.

[35] Littlejohn, A., Beetham, H. and McGill, L., Learning at the digital frontier: a review of digital literacies in theory and practice, Journal of computer assisted learning, vol. 28, No. 6, pp. 547-556, 2012.

[36] Plowman, L., Stevenson, O., McPake, J., Stephen, C. and Adey, C., Parents, preschoolers and learning with technology at home: some implications for policy, Journal of computer assisted learning, vol. 27, No. 4, pp. 361-371, 2011.

[37] Hess, S.A., Digital media and student learning: Impact of electronic books on motivation and achievement, New England Reading Association Journal, vol. 49, No. 2, p. 35, 2014.

[38] Lysenko, L.V. and Abrami, P.C., Promoting reading comprehension with the use of technology, Computers \& Education, vol. 75, pp. 162-172. 2014.

[39] Hsu, C.Y., Tsai, C.C. and Wang, H.Y, Facilitating third graders' acquisition of scientific concepts through digital game-based learning: The effects of self explanation principles, The Asia-Pacific Education Researcher, vol. 21, No. 1, pp. 71-82, 2012.

[40] Guven, G. and Sulun, Y., The Effects of Computer-Enhanced Teaching on Academic Achievement in 8th Grade Science and Technology Course and Students' Attitudes towards the Course, Journal of Turkish Science Education, vol. 9, No. 1, 2012.

[41] Reed, P., Hughes, A. and Phillips, G., Rapid recovery in sub-optimal readers in Wales through a self-paced computer-based reading programme, British Journal of Special Education, vol. 40, No. 4, pp. $162-166,2013$.

[42] Tamim, R.M., Bernard, R.M., Borokhovski, E., Abrami, P.C. and Schmid, R.F., What forty years of research says about the impact of technology on learning: A second-order meta-analysis and validation study, Review of Educational research, vol. 81, No. 1, pp. 4-28, 2011.

[43] Contento, I.R., Nutrition education: linking research, theory, and practice, Asia Pacific journal of clinical nutrition, vol. 17, No. S1, pp. 176-179, 2008.

[44] Samieipour, S., Rahimzade, R., Naghdi, N., Pakseresht, M., Tavassoli, E., Babaei Heydarabadi, A., Sayehmiri, K., Abedzadeh Zavareh, M.S., Asadi-Samani, M. and Bahmani, M., Investigation of the effect of education on nutritional knowledge, attitude and performance of primary school students in Ilam-2015, Journal of Chemical and Pharmaceutical Sciences, vol. 9, No. 3, pp. 1210-1215, 2016.

[45] Kupolati, M.D., Gericke, G.J. and MacIntyre, U.E.Teachers' perceptions of school nutrition education's influence on eating behaviours of learners in the Bronkhorstspruit District, South African Journal of Education, vol. 35, No. 2, pp. 01-10, 2015.

[46] Kupolati, M.D., MacIntyre, U.E. and Gericke, G.J., School-based nutri- tion education: features and challenges for success, Nutrition\& Food Science, vol. 44, No. 6, pp. 520-535, 2014.

[47] Rosário, R., Oliveira, B., Araújo, A., Lopes, O., Padrão, P., Moreira, A., Teixeira, V., Barros, R., Pereira, B. and Moreira, P. The impact of an intervention taught by trained teachers on childhood overweight, International journal of environmental research and public health, vol. 9, No. 4, pp. 1355-1367, 2012.

[48] Ercan, O., the effects of multimedia learning material on students' academic achievement and attitudes towards science courses, Journal of Baltic Science Education, vol. 13, No, 5, 2014.

[49] Cooper, S.B., Bandelow, S. and Nevill, M.E., Breakfast consumption and cognitive function in adolescent schoolchildren, Physiology \& Behavior, vol. 103, No. 5, pp. 431-439, 2011.

[50] O'Dea, J.A. and Abraham, S.Knowledge, beliefs, attitudes, and behaviors related to weight control, eating disorders, and body image in Australian trainee home economics and physical education teachers, Journal of nutrition education, vol. 33, No. 6, pp. 332-340, 2001.

[51] Sharma, P. and Rani, M.U., Effect of Digital Nutrition Education Intervention on the Nutritional Knowledge Levels of Information Technology Professionals, Ecology of food and nutrition, vol. 55, No. 5, pp. 442455. 2016.

[52] Bogden, N,Technology and Nutrition: Interactive Strategies for Children to Learn Nutrition, 2015.

[53] Baturay, M.H., Gökçearslan, S. and Ke, F.,The relationship among pre-service teachers' computer competence, attitude towards computerassisted education, and intention of technology acceptance, International Journal of Technology Enhanced Learning, vol. 9, No. 1, pp. 1-13, 2017.

[54] Awan, R.N., What Happens to Teachers ICT Attitudes and Classroom ICT Use when Teachers are made to Play Computer Games?, International Journal of Information and Education Technology, vol. 1, No. 4, p. 354, 2011.

[55] Mumtaz, S., Factors affecting teachers' use of information and communications technology: a review of the literature, Journal of information technology for teacher education, vol. 9, No. 3, pp. 319-342, 2000.

[56] Meerza, A.H. and Beauchamp, G., Factors influencing attitudes towards information and communication technology (ICT) amongst undergraduates, An empirical study conducted in Kuwait Higher Education Institutions (KHEIS) 2017.

[57] Rhoda, C. and Gerald, K., Internal Consistency Reliabilities for 14 computers. Attitude scale, Journal of Education technology, vol. 14, No. 4, pp. 99-120, 2000.

[58] Bates, A.T., Technology, e-learning and distance education., Routledge, 2005.

[59] Russell, M., Bebell, D., O'Dwyer, L. and O'Connor, K., Examining teacher technology use: Implications for preservice and inservice teacher preparation, Journal of teacher Education, vol. 54, No. 4, pp. 297-310, 2003.

[60] Christensen, R., Effects of technology integration education on the attitudes of teachers and students, Journal of Research on technology in Education, vol. 34, No. 4, pp. 411-433, 2002.

[61] Balta, N. and Duran, M., Attitudes of students and teachers towards the use of interactive whiteboards in elementary and secondary school classrooms, TOJET: The Turkish Online Journal of Educational Technology, vol. 14, No. 2, 2015.

[62] Enayati, T., Modanloo, Y. and Kazemi, F.S.M., Teachers' attitudes towards the use of technology in education, Journal of Basic and Applied Scientific Research, vol. 2, No. 11, pp. 10958-10963, 2012.

[63] Dogruer, N., Eyyam, R. and Menevis, I. The attitudes of English preparatory school instructors towards the use of instructional technology in their classes, Procedia Social and Behavioral Sciences, vol. 15, No. 2, pp. 5095-5099, 2010.

[64] Ozdaml, F., Hursen, Ç. and Ozçinar, Z., Teacher candidates' attitudes towards the instructional technologies, Procedia-Social and Behavioral Sciences, vol. 1, No. 1, pp.455- 463, 2009.

[65] Kabadayi, A. (2006) Analyzing Pre-School Student Teachers' and Their Cooperating Teachers' Attitudes towards the Use of Educational Technology, The Turkish Online Journal of Educational Technology (TOJET), vol. 5, No. 4, 2006. 
[66] Zanguyi, S., Review of teachers' attitudes towards the use of educational technology in teaching process, Educational Technology, vol. 6, pp. 165-159, 2011.

[67] Seraji, N.E., Ziabari, R.S. and Rokni, S.J.A., Teacher's Attitudes towards Educational Technology in English Language Institutes, International Journal of English Linguistics, vol. 7, No. 2, p. 176, 2017.

[68] Chow, P. Teacher's Attitudes towards Technology in The Classroom, 2014.

[69] Albirini, Teachers' attitudes toward information and communication technologies, The case of Syrian EFL teachers Computers \& Education, vol. 47, No. 4, pp. 373-398, 2006

[70] Buabeng-Andoh, C., Factors influencing teachers' adoption and integration of information and communication technology into teaching. A review of the literature, International Journal of Education and Development using Information and Communication Technology, vol. 8, No. 1, p. 136, 2012.

[71] Al-Emran, M., Elsherif, H.M. and Shaalan, K., Investigating attitudes towards the use of mobile learning in higher education, Computers in Human Behavior, vol. 56, pp. 93-102, 2016.

[72] Hwang, G.J. and Chang, H.F., A formative assessment-based mobile learning approach to improving the learning attitudes and achievements of students, Computers \& Education, vol. 56, No, 4, pp. 1023-1031, 2011.

[73] Shroff, R.H., Deneen, C.C. and Ng, E.M. Analysis of the technology acceptance model in examining students' behavioural intention to use an e-portfolio system, Australasian Journal of Educational Technology, vol. 27, No. 4, 2011

[74] Tseng, K.H., Chang, C.C., Lou, S.J. and Chen, W.P., Attitudes towards science, technology, engineering and mathematics (STEM) in a project-based learning $(P j B L)$ environment, International Journal of Technology and Design Education, vol. 23, No. 1, pp. 87-102, 2013.

[75] Al-Fraihat, D., Joy, M. and Sinclair, J. Identifying Success Factors for eLearning in Higher Education, Proceedings of the 12th International Conference on e-Learning (ICEL), p. 247, 2017.

[76] Condie, R. and Munro, B., The impact of ICT in schools: Landscape review, British Educational Communications and Technology Agency (BECTA), Corp Creator, 2007.

[77] Burden, K. and Hopkins, P., Barriers and Challenges Facing Preservice Teachers use of Mobile Technologies for Teaching and Learning, In Blended Learning: Concepts, Methodologies, Tools, and Applications, IGI Global, pp. 1665-1686., 2017.

[78] Osang, F.B., Ngole, J. and Tsuma, C., February. Prospects and Challenges of Mobile Learning Implementation in Nigeria, Case Study National Open University of Nigeria NOUN, In International Conference on ICT for Africa, pp. 20-23, 2013.

[79] Blinco, K., Mason, J., McLean, N. and Wilson, S., Trends and issues in e-learning infrastructure development, 2004.

[80] Tondeur, J., van Braak, J., Ertmer, P.A. and Ottenbreit-Leftwich, A., Understanding the relationship between teachers' pedagogical beliefs and technology use in education: a systematic review of qualitative evidence, Educational Technology Research and Development, vol 65, No. 3, pp. 555-575, 2017.

[81] Voogt, J. and Knezek, G. eds., International handbook of information technology in primary and secondary education, Springer Science \& Business Media, vol. 20, 2008.

[82] Sethi, K.K., Bhanodia, P., Mishra, D.K., Badjatya, M. and Gujar, C.P., Challenges Faced in Deployment of e-Learning Models in India, In Proceedings of the International Congress on Information and Communication Technology, Springer, Singapore, pp. 647- 655, 2016.

[83] Mayes, R., Natividad, G. and Spector, J.M., Challenges for educational technologists in the 21st century, Education Sciences, vol. 5, No. 3, pp. 221-237, 2015

[84] Anderson, J.L. and Barnett, M. Learning physics with digital game simulations in middle school science, Journal of Science Education and Technology, vol. 22, No. 6, pp. 914-926, 2013.

[85] Paraskeva, F., Mysirlaki, S. and Papagianni, A., Multiplayer online games as educational tools: Facing new challenges in learning, Computers \& Education, 54(2), pp.498-505. 2010.

[86] Campbell, C.,Study finds smarter students plav online games. 2016. Retrieved from Polygon: https://www.polygon.com/2016/8/8/12406388/ online-games-educationbenefit
[87] Young, M.F., Slota, S., Cutter, A.B., Jalette, G., Mullin, G., Lai, B., Simeoni, Z., Tran, M. and Yukhymenko, M., Our princess is in another castle: A review of trends in serious gaming for education, Review of educational research, vol. 82, No. 1, pp.61-89, 2012.

[88] Kapp, K.M., The gamification of learning and instruction: game-based methods and strategies for training and education, John Wiley \& Sons, 2012.

[89] Squire, K.D., Video games and education: Designing learning systems for an interactive age, Educational Technology, pp. 17-26, 2008.

[90] Amory, A., Game object model version II: a theoretical framework for educational game development, Educational Technology Research and Development, vol. 55, No. 1, pp. 51-77, 2007.

[91] Kuipers, F., Märtens, M., van der Hoeven, E. and Iosup, A., The Power of Social Features in Online Gaming, Social Interactions in Virtual Worlds: An Interdisciplinary Perspective, 2018.

[92] Livingstone, S., Mascheroni, G. and Staksrud, E., European research on children's internet use: Assessing the past and anticipating the future, New Media \& Society, vol. 20, No. 3, pp. 1103-1122, 2018.

[93] Institute of Digital Media and Child Development Working Group on Games for Health, Baranowski, T., Blumberg, F., Buday, R., DeSmet, A., Fiellin, L.E., Green, C.S., Kato, P.M., Lu, A.S., Maloney, A.E. and Mellecker, R., Games for health for children-Current status and needed research, Games for health journal, vol. 5, No, 1, pp. 1- 12. 2016.

[94] Taylor, J., How technology is changing the way children think and focus. Psychology Today, 2012, Retrieved from https://www.psychologytoday.com/blog/the-powerprime/201212/ how-technology-is-changing-the-way-children-think-and-focus

[95] Granic, I., Lobel, A. and Engels, R.C., The benefits of playing video games, American psychologist, vol. 69, No. 1, p. 66, 2014.

[96] KidsHealth, Mission nutrition, The Nemours Foundation, 2015, Retrieved from http://kidshealth.org/kid/closet/games/game_nutrition.html

[97] Annetta, L.A., Video games in education: Why they should be used and how they are being used, Theory into practice, vol. 47, No. 3, pp. 229-239, 2008.

[98] Connolly, T.M., Boyle, E.A., MacArthur, E., Hainey, T. and Boyle, J.M., A systematic literature review of empirical evidence on computer games and serious games., Computers \& Education, vol. 59, No. 2, pp. 661-686, 2012.

[99] Whole Kids Foundation, Awesome eats, Whole Kids Foundation, 2014, Retrieved from https://www.wholekidsfoundation.org/ kids-activities/awesome-eats/

[100] Fisher, C., Designing games for children: developmental, usability, and design considerations for making games for kids. 2014, Retrieved from https://books.google.com/books?id=ZxlWBQAAQBAJ\&printsec= frontcover\&source=gbs_atb\# $\mathrm{v}=$ onepage $\& \mathrm{q} \& \mathrm{f}=\mathrm{false}$

[101] Brannen, J., Mixing methods: Qualitative and quantitative research, Routledge. 2017.

[102] Bryman, A., Quantitative and qualitative research: further reflections on their integration, In Mixing methods: Qualitative and quantitative research, Routledge, pp. 57-78, 2017.

[103] Choy, L.T. (2014) The strengths and weaknesses of research methodology: Comparison and complimentary between qualitative and quantitative approaches, Journal of Humanities and Social Science (IOSR), vol. 19, No. 4, pp. 99-104, 2014.

[104] Kelle, U. and Buchholtz, N., The combination of qualitative and quantitative research methods in mathematics education: A "mixed methods" study on the development of the professional knowledge of teachers, In Approaches to qualitative research in mathematics education, Springer, Dordrecht, pp. 321-361., 2015.

[105] McCusker, K. and Gunaydin, S., Research using qualitative, quantitative or mixed methods and choice based on the research, Perfusion, vol. 30, No. 7, pp. 537-542, 2015.

[106] Barnham, C., Quantitative and qualitative research: Perceptual foundations, International Journal of Market Research, vol. 57, No. 6, pp. 837-854, 2015.

[107] Hammersley, M., Deconstructing the qualitative-quantitative divide 1 In Mixing methods: Qualitative and quantitative research, Routledge, pp. 39-55, 2017. 
[108] Larson-Hall, J. and Plonsky, L., Reporting and interpreting quantitative research findings: What get reported and recommendations for the field, Language Learning, vol. 65, No. S1, pp. 127-159, 2015.

[109] Landrum, B. and Garza, G., Mending fences: Defining the domains and approaches of quantitative and qualitative research, Qualitative Psychology, vol. 2, No. 2, p. 199, 2015.

[110] Heale, R. and Twycross, A. Validity and reliability in quantitative studies, Evidence-based nursing, 2015. 